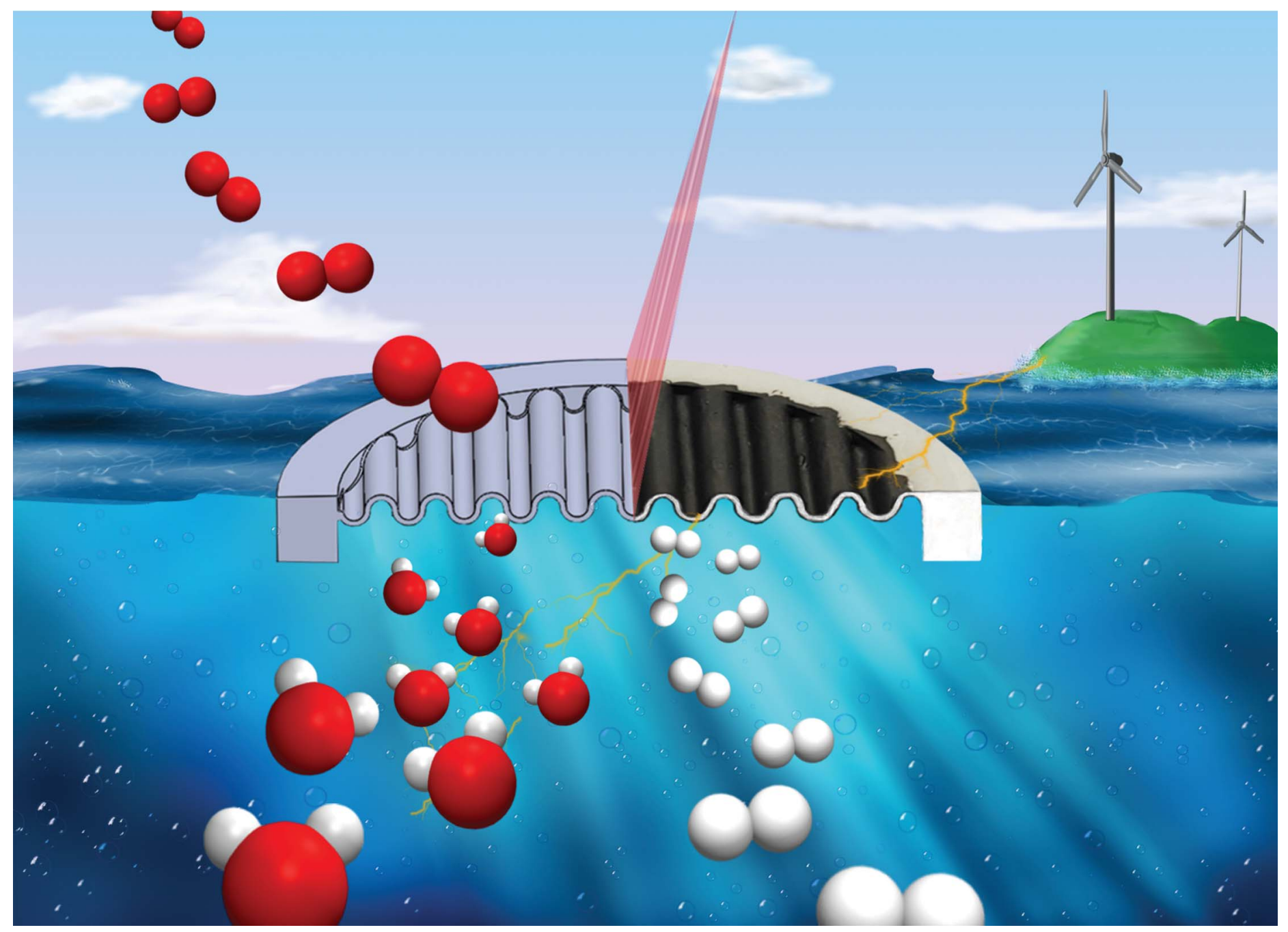

Highlighting a study on the 3D printing of solid oxide cells carried out by the group of ICREA Prof. Albert Tarancón at the Catalonia Institute for Energy Research (IREC), Spain.

3D printing the next generation of enhanced solid oxide fuel and electrolysis cells

A new family of 3D printed solid oxide cells is presented. An innovative approach based on high-aspect ratio corrugated cells increases their performance by $60 \%$ in SOFC and co-electrolysis modes.

\section{As featured in:}

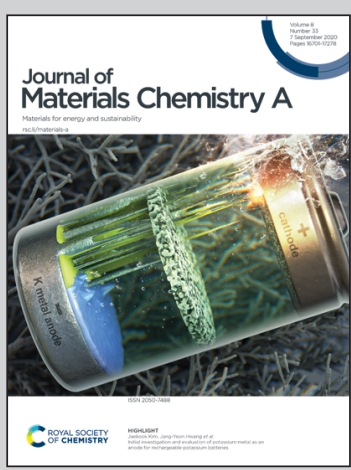

See Albert Tarancón et al., J. Mater. Chem. A, 2020, 8, 16926. 
Check for updates

Cite this: J. Mater. Chem. A, 2020, 8 , 16926

\title{
3D printing the next generation of enhanced solid oxide fuel and electrolysis cells $\uparrow$
}

\author{
Arianna Pesce, (D) a Aitor Hornés, ${ }^{a}$ Marc Núñez, ${ }^{a}$ Alex Morata, (D) a Marc Torrell ${ }^{a}$ \\ and Albert Tarancón (iD *ab
}

\begin{abstract}
3D printing of functional materials will revolutionize the energy sector by introducing complex shapes and novel functionalities never explored before. This will give rise to the next generation of enhanced devices ready for mass customization. Among others, electroceramic-based energy devices like solid oxide fuel and electrolysis cells are promising candidates to benefit from using 3D printing to develop innovative concepts that overcome shape limitations of currently existing manufacturing techniques. In this work, a new family of highly performing electrolyte-supported solid oxide cells were fabricated using stereolithography. Conventional planar and high-aspect ratio corrugated electrolytes were 3Dprinted with yttria-stabilized zirconia to fabricate solid oxide cells. Corrugated devices presented an increase of $57 \%$ in their performance in fuel cell and co-electrolysis modes, which is straightforwardly proportional to the area enlargement compared to the planar counterparts. This enhancement by design combined to the proved durability of the printed devices (less than $35 \mathrm{mV}$ / $1000 \mathrm{~h}$ ) represents a radically new approach in the field and anticipates a strong impact in future generations of solid oxide cells and, more generally, in any solid state energy conversion or storage devices.
\end{abstract}

Received 10th March 2020

Accepted 20th May 2020

DOI: $10.1039 / \mathrm{d} 0 \operatorname{ta} 02803 \mathrm{~g}$

rsc.li/materials-a
Solid oxide cells (SOCs) are ceramic-based multilayer electrochemical cells consisting of a gas-tight oxide-ionic conductor electrolyte with electrodes in both sides. The state of the art materials for SOCs are yttria-stabilized zirconia (YSZ) for the electrolyte, combined with YSZ-based composites as electrodes, namely, lanthanum strontium manganite (LSM-YSZ) for the oxygen electrode and Ni-YSZ for the fuel electrode. ${ }^{6-8}$ Beyond these well-known materials, other compounds such as scandiastabilized zirconia (SSZ) or $\mathrm{La}_{x} \mathrm{Sr}_{1-x} \mathrm{Co}_{y} \mathrm{Fe}_{1-y} \mathrm{O}_{3-d}$ (LSCF) are currently employed by the industry as electrolytes or oxygen electrodes, respectively, to increase the performance of the cells at lower operation temperatures $\left(T<800{ }^{\circ} \mathrm{C}\right) .{ }^{\mathbf{9}, 10}$ However, stability problems of SSZ under high current densities in SOEC mode $^{11}$ and the need of diffusion barrier layers between YSZ and LSCF $^{12,13}$ still make the conventional LSM-YSZ/YSZ/Ni-YSZ combination a competitive cell, even operating at elevated temperatures $\left(T>800{ }^{\circ} \mathrm{C}\right)$.

While big efforts have been dedicated in the last decades to develop new materials, ${ }^{9}$ only few strategies have been explored to take advantage of a straightforward increase of the performance of the cells by modification of its geometry, likely due to the strict limitations in manufacturing complex ceramic shapes. For instance, an increase of the active area of the cells by corrugation of the electrolyte will directly reduce the internal resistance of the cell, i.e. its area specific resistance $(\mathrm{ASR}=R / A)$, proportionally increasing their performance per projected area. In this direction, Prinz et al. ${ }^{\mathbf{1 4 , 1 5}}$
${ }^{a}$ IREC, Catalonia Institute for Energy Research, Jardins de les Dones de Negre $1,2^{\circ} \mathrm{pl}$, 08930 Sant Adrià de Besòs, Barcelona, Spain.E-mail: atarancon@irec.cat ${ }^{b}$ ICREA, Passeig Lluís Companys 23, 08010, Barcelona, Spain

$\dagger$ Electronic supplementary information (ESI) available. See DOI: 10.1039/d0ta02803g 
proved a two-fold increase of power density in silicon-based micro-SOFCs corrugated YSZ thin film electrolytes. Despite this successful experience, to the best of the authors' knowledge, similar strategies have not been used in conventional SOFCs although the benefits of controlling the geometry of the cell at the microscale can be easily anticipated. This is likely because free-form manufacturing techniques such as $3 \mathrm{D}$ printing have demonstrated only very recently their suitability for fabricating highly complex dense ceramic parts with good mechanical properties. ${ }^{16,17}$ In this direction, Ruiz-Morales et al. ${ }^{18}$ lately reviewed the use of 3D printing for energy applications suggesting the interest of stereolithography (SLA) printing for developing high aspect ratio highly performing SOFCs. According to Ruiz-Morales, the different works devoted to the development of SOFCs by 3D printing were focused on the fabrication of planar cells ${ }^{19-31}$ with the only exception of the one recently published by the authors ${ }^{32}$ in which honeycomb structures were used to improve the mechanical stability of $3 \mathrm{D}$ printed $\mathrm{YSZ}$ membranes.

In this work, planar and high-aspect ratio corrugated LSMYSZ/YSZ/Ni-YSZ solid oxide cells have been fabricated. This approach has been only possible by the use of 3D printing technologies, which opens the possibility of manufacturing near free-shape designs. More specifically, this work presents the fabrication of $250 \mu \mathrm{m}$-thick $8 \mathrm{YSZ}$ ( $8 \mathrm{~mol} \%$ yttria-stabilized zirconia) electrolytes by SLA with a corrugated architecture, which intrinsically increases around $60 \%$ the active area compared to an also printed planar counterpart. A comprehensive characterization of the electrochemical performance of both types of cells is presented in this work in a range of temperatures between $800-900{ }^{\circ} \mathrm{C}$ in fuel cell and $\mathrm{CO}_{2}$ and steam co-electrolysis modes. The analysis of the impedance spectroscopy of the cells allowed the clear identification of the origin of the enhancement. The corrugated architecture is discussed here as a first example of the wide range of printable geometries that can be fabricated by the ceramic 3D printing approach proposed in this work, proving its unfair advantage improving the performance of the so obtained cell.

\section{Experimental method}

Planar and corrugated YSZ ceramic pieces were fabricated by using the stereolithography (SLA) printing method (Fig. 1a) within a ceramic 3D printer (CERAMAKER from 3DCERAM, France) (Fig. 1b and c). Computer Assisted Design (CAD) software was employed to sketch planar and corrugated membranes of the same $2.00 \mathrm{~cm}$ in diameter (of which $1.6 \mathrm{~cm}$ is the diameter for the electrode deposition, determining the future active area of the cell) and $250 \mu \mathrm{m}$ in thickness but with different effective surface areas of 2.00 and $3.15 \mathrm{~cm}^{2}$, respectively. Such membranes were monolithically integrated with external annular rings to enhance the mechanical stability and ensure good sealing of the membranes during the testing (see a detailed description elsewhere ${ }^{32}$ ). To obtain the dimensions here described after the sintering, a rescaling process is applied to take into account the shrinkage during the sintering process (initial design values are not reported for clarity reasons). STL files were automatically created by using DMC software to slice the design and control the 3D printer. A solvent-free UV-photocurable slurry (3DMIX-8YSZ®, 3DCERAM, France) composed by 8YSZ ceramic powder, acrylate UV curable monomer, photoinitiator and dispersant is employed. The substitution of solvents by photo-polymerizable binders allows to achieve high ceramic loading, good homogeneity and a low viscosity of the suspension, which is further improved by adding diluents. ${ }^{33}$ 8YSZ slurry with high ceramic loading ( $c a$. $50 \mathrm{vol} \%$ ) was deposited over a $30 \times 30 \mathrm{~cm}^{2}$ printing platform by a double doctor blade system able to homogeneously spread the paste. The blades were adjusted to deposit a thin layer of $25 \mu \mathrm{m}$ in thickness. After deposition of the photocurable slurry, a UV semiconductor laser (power around 500 $\mathrm{mW}$ ) focused at the building platform reproduces, slice by slice, the pattern designed by CAD using mirror rastering with a speed of $5000 \mathrm{~mm} \mathrm{~s}^{-1}$. Under UV exposure, the photocurable slurry, containing a monomer and a photoinitiator active in the UV region, ${ }^{34}$ locally solidifies following a freeradical photo-polymerisation process..$^{33,35,36}$ This process
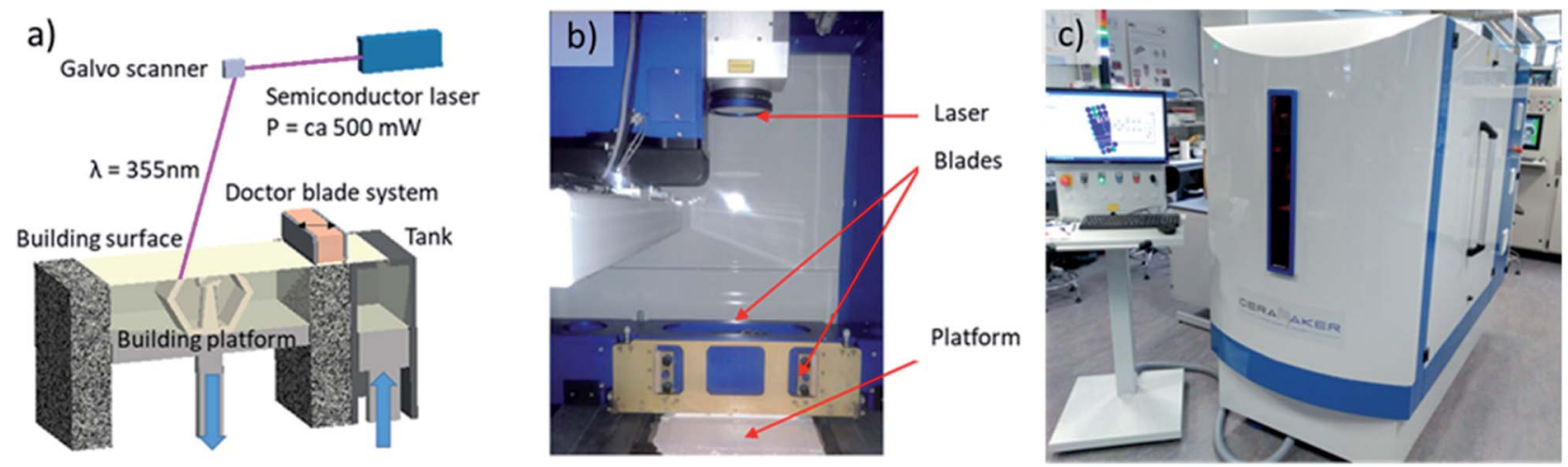

Fig. 1 (a) Scheme of the working principle of the SLA printing process where a building platform is filled, layer by layer, with a photocurable paste with high ceramic loading that is cured following a certain pattern by a UV-laser able to raster the whole area. (b) Inside view of the machine during a printing process, (c) ceramic 3D printer by 3DCERAM, France, used in this work. 
(lowering the platform, supplying the slurry and cure by laser rastering) is repeated as many times as layers of $25 \mu \mathrm{m}$ are required to generate the desired three-dimensional structure. At the end of the printing process, the uncured paste was removed from the platform for extracting the consolidated pieces. This paste can be reused for following printings without further processing. The uncured paste remaining within the structure can only be recovered after dilution during the cleaning process. In this way, the solid loading is fully recycled having virtually null ceramic waste. Clean parts were thermally treated for more than $70 \mathrm{~h}$ in inert atmosphere to eliminate the organics without crack formation within the green bodies. Finally, the pieces were sintered at $1300{ }^{\circ} \mathrm{C}$ for $4 \mathrm{~h}$ (heating and cooling rate of $3 \mathrm{~K} \mathrm{~min}^{-1}$ ) in oxidizing atmosphere generating a dense ceramic piece of 8 YSZ. The density of the ceramics was calculated by dividing the mass measured with a balance by the volume obtained by geometrical calculations. Symmetrical and full electrochemical cells were fabricated using previously optimized standard procedures. Commercial NiO-YSZ and LSM-YSZ pastes (Fuel cell materials, USA) were painted on 3D printed YSZ pieces as fuel and oxygen electrodes, respectively. Attachment temperatures of $1400{ }^{\circ} \mathrm{C}$ for $3 \mathrm{~h}$ (ramp rate 1 $\mathrm{K} \min ^{-1}$ ) and $1200{ }^{\circ} \mathrm{C}$ for $1 \mathrm{~h}\left(\right.$ ramp rate $1 \mathrm{~K} \mathrm{~min}^{-1}$ ) were employed for the fuel and oxygen electrodes, respectively. Microstructural characterization of the printed pieces and the full cells has been carried out using an AURIGA Scanning Electron Microscope (SEM) from ZEISS (Germany) in top-view and cross-section modes. In order to determine the crystal structure of the materials under study XRD and Raman spectroscopy were carried out in an automatic X-rays diffractometer (Bruker D8 Advance, USA) equipped with $\mathrm{Cu}$ $\mathrm{K} \alpha$ radiation $(1.5418 \AA$ ) and a Horiba Spectrometer HR800 (LabRAM Series, Horiba Jobin Yvon, France), respectively.

Electrochemical cells were characterized in automatic test benches based on commercial Probostat test stations (NORECS, Norway). A gas mixer panel consisting of several massflow controllers connected in parallel $\left(\mathrm{H}_{2}, \mathrm{CO}_{2}\right.$, air) and able to introduce high amounts of water vapour (CEM, Bronkhorst, Netherlands) is employed to properly adjust the gas input in SOFC and co-SOEC test modes. Electrical outputs were connected to galvanostat/potentiostat and frequency response analyser (Parstat 2273, PAR, USA) equipment to evaluate the performance of the cells by studying their polarization $V-I$ curves and carrying out Electrochemical Impedance Spectroscopy (EIS). The analysis of the obtained Nyquist plots was carried out by fitting the obtained arcs using equivalent circuits and ZView software. Symmetrical cells were evaluated in a temperature range of $400-900{ }^{\circ} \mathrm{C}$ under symmetrical atmosphere of synthetic air. Full cells were measured at 800,850 and $900{ }^{\circ} \mathrm{C}$ after being conveniently sealed to form two gas-tight chambers with pure hydrogen and air (in fuel cell mode) or $\mathrm{CO}_{2} / \mathrm{H}_{2} \mathrm{O} / \mathrm{H}_{2}$ mixtures and air (in co-electrolysis mode). Mid-term stability tests $(>300 \mathrm{~h})$ of full cells were performed under SOFC mode, in the already described set-up, applying $360 \mathrm{~mA} \mathrm{~cm}^{-2}(0.7 \mathrm{~V})$ at $850{ }^{\circ} \mathrm{C}$.

\section{Results}

\section{Fabrication and characterization of high aspect ratio 3D printed YSZ electrolytes}

Planar and corrugated 8YSZ freestanding membranes were fabricated by means of SLA 3D printing after sintering at high temperatures. As shown in Fig. 2a and b, crack-free and homogeneous parts were obtained. Despite a similar projected area of $2.00 \mathrm{~cm}^{2}$, planar and corrugated membranes showed different effective surface areas of $2.00 \mathrm{~cm}^{2}$ and $3.15 \mathrm{~cm}^{2}$, respectively, which represents an increase of $57 \%$ in area. Moreover, annular rings were integrated in the design to ensure a good mechanical stability of the membrane and facilitate later sealing to the test stations. Fig. 2 also shows cross-section images of the complete planar (Fig. 2c) and corrugated cells (Fig. 2d) with higher magnification SEM images of the electrolyte membranes (Fig. 2e and f). The thickness of the YSZ layer in both types of cells is of $270 \mu \mathrm{m}$ with a standard deviation of \pm 18 $\mu \mathrm{m}$, which proves an excellent thickness uniformity even for highly complex shapes. This electrolyte thickness homogeneity avoids the formation of detrimental hot spots in operation caused by Joule effect when high current densities are passing through thinner regions. In this regard, the inset in Fig. $2 f$ shows the typical height of the layer-by-layer 3D printing step (estimated in $25 \mu \mathrm{m}$ ), which determines the accuracy in the $z$ and $x-y$-axes of the here presented methodology. The sintered membranes of 8YSZ were further analysed with XRD and Raman spectroscopy (ESI, Fig. S1 $\dagger$ ) confirming the partial stabilization of the cubic phase without the presence of deleterious monoclinic phase. Moreover, the ionic transport of the YSZ membranes was measured using them as electrolytes in
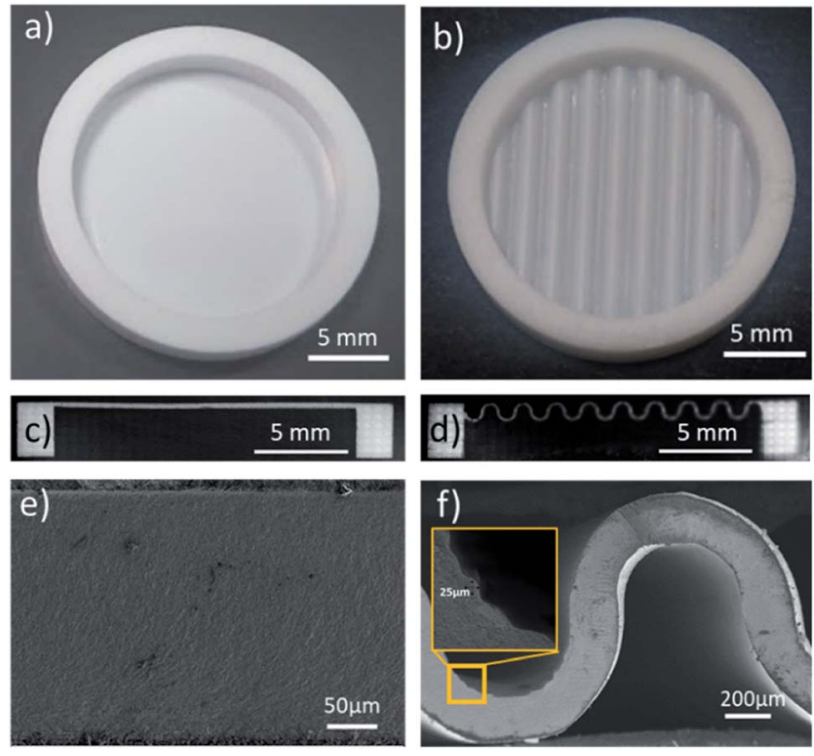

Fig. 2 Images of the self-standing 3D printed 8YSZ membranes. Top view ( $a$ and $b$ ) and cross-section ( $c$ and d) of the planar and corrugated membranes, respectively. Detail of the cross-section by SEM for the planar (e) and corrugated (f) electrolytes showing (in the inset) the steps defined with the layer-by-layer 3D printing process. 
symmetrical electrochemical cells in the temperature range from 400 to $900{ }^{\circ} \mathrm{C}$ (see details in ESI, Fig. S2 $\dagger$ ). An Arrhenius behaviour with values of conductivity above $3.0 \times 10^{-2} \mathrm{~S} \mathrm{~cm}^{-1}$ at $800{ }^{\circ} \mathrm{C}$ and an activation energy of $1.0 \mathrm{eV}$ were measured, which is in good agreement with transport properties typically reported in the literature for $\mathrm{YSZ}^{37}$ fabricated using conventional techniques. Overall, the 3D printed YSZ parts are considered suitable for working as electrolytes in SOFC/SOEC applications.

For the fabrication of complete solid oxide cells, LSM-YSZ and Ni-YSZ electrodes were deposited on both sides of the 3D printed 8YSZ sintered membranes using standard procedures. Fig. 3 shows cross-section SEM images of the different layers and interfaces for the planar (Fig. 3a, c, e and g) and corrugated cells (Fig. 3b, d, f and h). Regarding the electrolyte membrane (Fig. 3e and f), defect-free and homogeneous layers were observed in both cells with density above $97 \%$ of the theoretical value $\left(6.10 \mathrm{~g} \mathrm{~cm}^{-3}\right)$. Limited closed porosity was observed in the electrolyte indicating the suitability of the 3D printing technology to reach gas-tight self-standing membranes. The gastightness of the printed electrolytes was later confirmed by the open circuit voltage (OCV) obtained in fuel cell mode (see next section). Despite the full densification of the YSZ

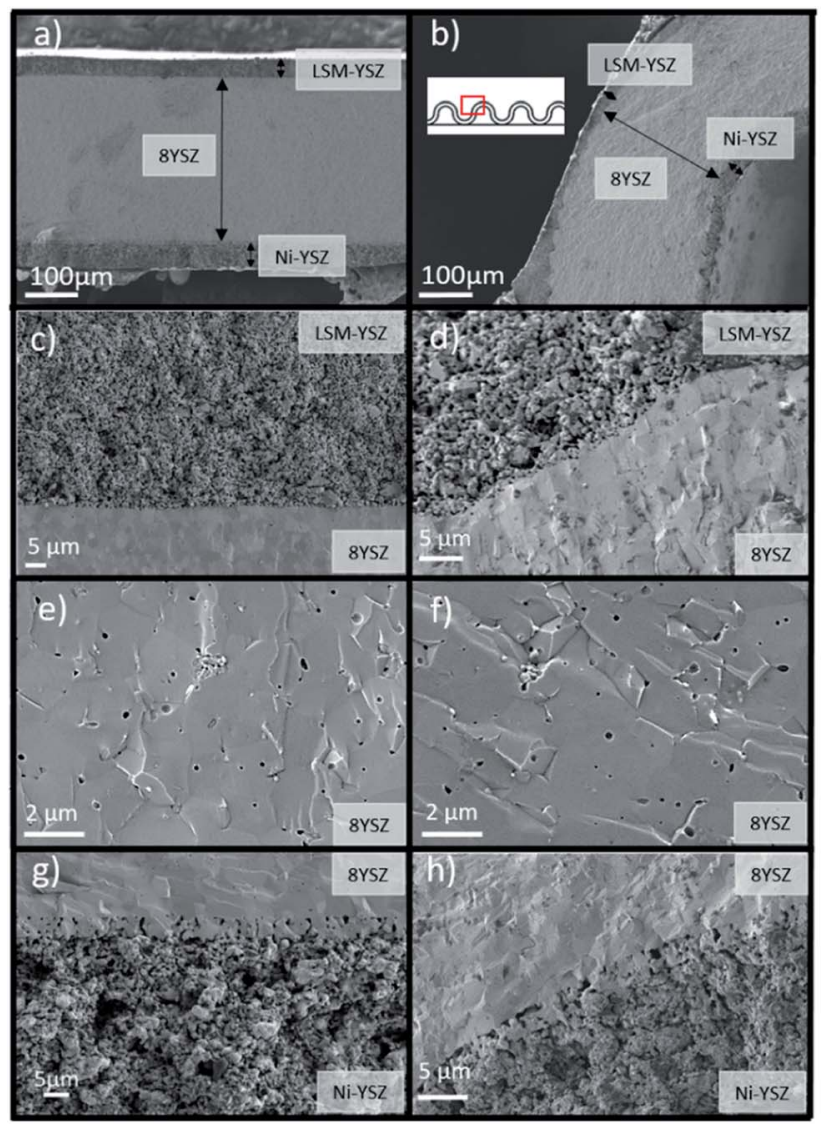

Fig. 3 Cross-section SEM images of the planar (a, c, e and g) and corrugated ( $b, d, f$ and $h$ ) cells. Detail of the LSM-YSZ oxygen electrode, the YSZ electrolyte and the Ni-YSZ fuel electrode and their combined interfaces are presented for both types of cells. electrolyte, good adhesion of the air and fuel electrodes was confirmed by detailed observation of the interfaces in the planar (Fig. 3c and g) and corrugated cells (Fig. 3d and h), overcoming the problems reported by Cebollero et al. ${ }^{38,39}$ Moreover, the same set of figures shows a suitable homogeneous and highly porous microstructure for the different electrodes confirming the high quality of the fabricated cells.

\section{Solid oxide cells performance in fuel cell and co-electrolysis modes}

The performance of the planar and corrugated LSM-YSZ/YSZ/ Ni-YSZ solid oxide fuel cells was evaluated by measuring polarization curves under hydrogen (fuel electrode) and synthetic air (oxygen electrode) atmospheres in the temperature range between $800{ }^{\circ} \mathrm{C}$ and $900{ }^{\circ} \mathrm{C}$. Fig. $4 \mathrm{a}$ and $\mathrm{c}$ show the $V-j$ polarization curves of both cells measured at $900{ }^{\circ} \mathrm{C}$ (results obtained at $800{ }^{\circ} \mathrm{C}$ and $850{ }^{\circ} \mathrm{C}$ are presented in the ESI, Fig. S4 and $\mathrm{S} 5 \dagger$ respectively). Open circuit voltages (OCVs) close to $1.10 \mathrm{~V}$ were measured for both cells, which is in good agreement with the expected values estimated by the Nernst law, confirming the gas tightness of the printed electrolytes (planar and corrugated) and the high quality of the measurement. The maximum power density $(P=V j)$ obtained at $900{ }^{\circ} \mathrm{C}$ for the planar cell reaches $P_{\mathrm{p}}=260 \mathrm{~mW} \mathrm{~cm}{ }^{-2}$, which is slightly above similar cells produced with conventional techniques compiled in ref. 40. More interestingly, the corrugated cell design presents $P_{\mathrm{c}}=410 \mathrm{~mW} \mathrm{~cm}{ }^{-2}$, which corresponds to an increase of $57 \%$ in power compared to the planar. This improvement, which is roughly maintained all along the whole range of tested temperatures (see Fig. S4 and S5 $†$ ), is likely associated to the increase of the active area of the corrugated cell fixed by-design, i.e. $A_{\text {corr }} / A_{\text {plan }}=1.57$. In order to clearly split the different contributions to the total polarization resistance of the cells and, therefore, identify the origin of this enhancement, Electrochemical Impedance Spectroscopy (EIS) measurements were carried out for both cells (Fig. 4b). These different contributions can be obtained by deconvoluting the obtained spectra using a simple equivalent circuit consisting of an inductance $(L)$ in series with a resistance $\left(R_{\mathrm{YSZ}}\right)$ and two ZARC elements (see inset Fig. $4 \mathrm{~b}$ and d). The serial resistance ( $\left.R_{\mathrm{YSZ}}\right)$ can be mainly associated to the $8 Y S Z$ electrolyte while the addition of the resistance of the two ZARC elements $\left(R_{\mathrm{el}}=R_{\mathrm{el} 1}+R_{\mathrm{el} 2}\right)$ corresponds to the electrodes. Table 1 compiles all the resistances obtained by fitting the spectra in the form of area specific resistances (ASR = $R / A$, where $A$ is the projected area of the cell). First, it is worth remarking that ASR values measured for the printed planar cells $\left(\mathrm{ASR}_{\text {total }}=1.1 \Omega \mathrm{cm}^{2}\right)$ are comparable with conventional electrolyte supported cells previously reported by key players such as DTU (ASR $=1.1 \Omega \mathrm{cm}^{2}$ at $850{ }^{\circ} \mathrm{C}$ ), Jülich (ASR $=1.2 \Omega \mathrm{cm}^{2}$ at $800{ }^{\circ} \mathrm{C}$ ) or Westinghouse $\left(\mathrm{ASR}=1.0 \Omega \mathrm{cm}^{2}\right.$ at $\left.900{ }^{\circ} \mathrm{C}\right) .^{41}$ Compared to the reference printed planar cells, a significant ASR reduction is measured for the corrugated membranes. This decrease nearly corresponds to the one expected for the increase of area induced by design, i.e. $\mathrm{ASR}_{\text {corr }} / \mathrm{ASR}_{\text {plan }}=0.63$ (see Table 1) and is equally associated to the contributions of the electrolyte and the electrodes. Therefore, one can clearly conclude that 
a)

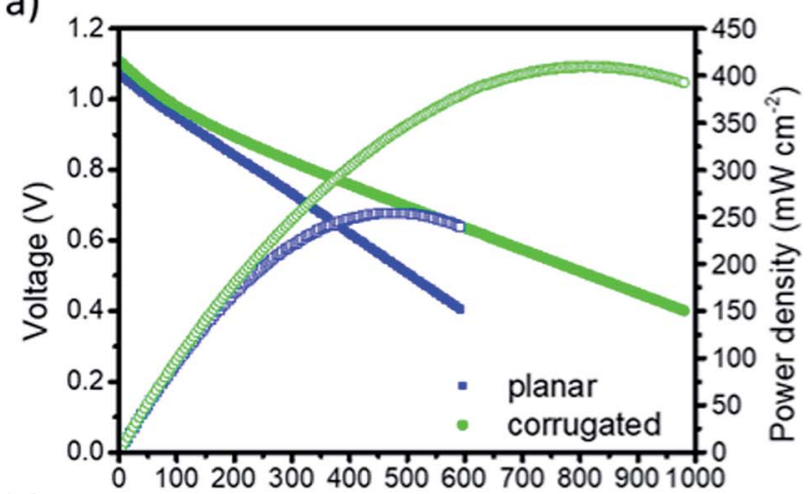

b)

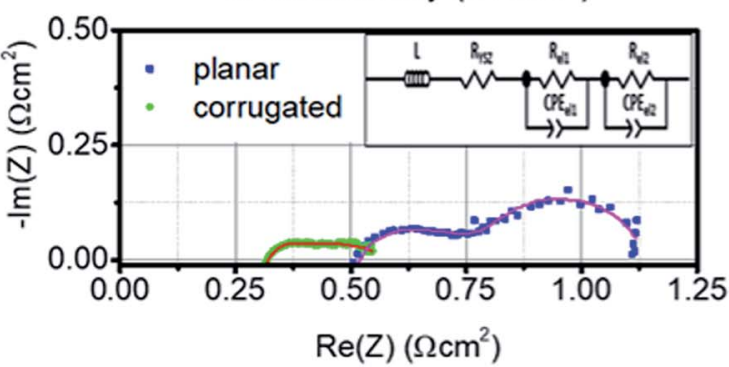

c)

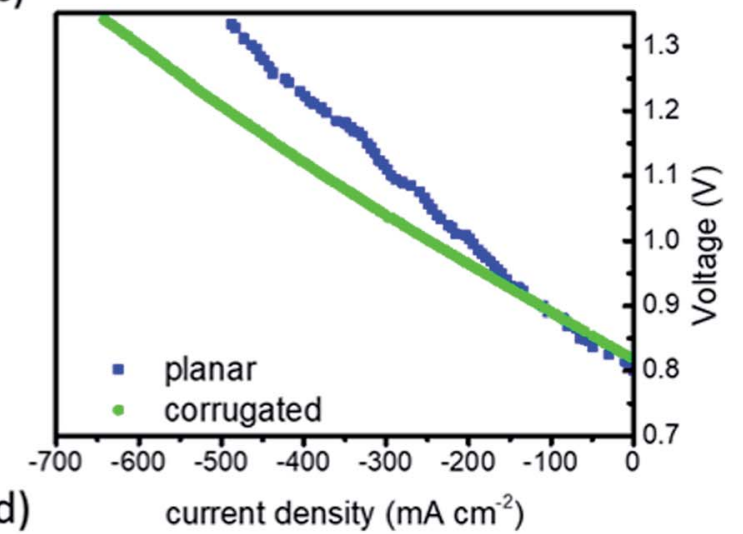

d)

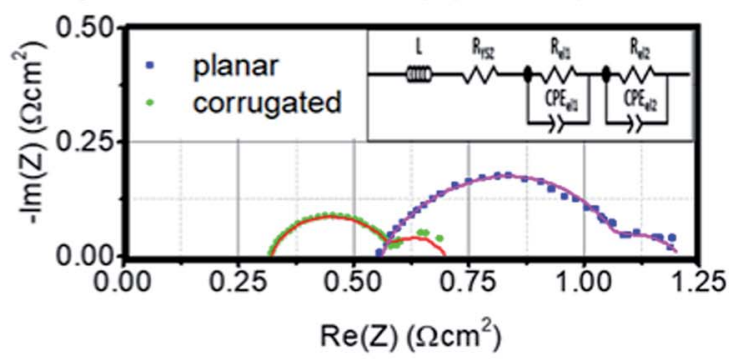

Fig. $4 \quad V$-j curves of the planar and corrugated cells measured in fuel cell (a) and co-electrolysis modes (b) at $900{ }^{\circ} \mathrm{C}$. Corresponding Nyquist plots from EIS measurements are represented for the fuel cell at $0.7 \mathrm{~V}$ (c) and co-electrolysis cell at $1.3 \mathrm{~V}$ (d).

the increase of area by corrugation has an equivalent positive impact in both the electrolyte and the electrodes, which indicates that all the dominating phenomena are directly proportional to the area as theorized by other studies ${ }^{42-44}$ (the same behaviour, with small variations in absolute values is maintained in all the temperature range).

In order to study the reversibility of the printed cells, the planar and corrugated LSM-YSZ/YSZ/Ni-YSZ printed cells were evaluated in co-electrolysis mode, converting a combination of steam and $\mathrm{CO}_{2}$ into syngas ( $\mathrm{CO}$ and hydrogen) by current injection at the same temperature $T=900^{\circ} \mathrm{C}$ (Fig. 4c). Similar OCV values (OCV $0.8 \mathrm{~V}$ ) were observed for both cells corresponding to the expected voltages for the specific combination of input gases. Although in this case it is not possible to determine a maximum performance (like the maximum power density calculated in SOFC), it is clear from the different slopes in the $V-j$ curves that the corrugated cell significantly improves the behaviour of the planar one, although a certain increase in the noise is observed due to steam supply issues. For a typical operation voltage of $V=1.3 \mathrm{~V}$, this improvement results in the injection of a current density of $600 \mathrm{~mA}$ $\mathrm{cm}^{-2}$ in the corrugated cell compared to $460 \mathrm{~mA} \mathrm{~cm}^{-2}$ available in the planar cell, i.e. corresponding to a $30 \%$ of enhancement. To clarify if the observed improvement correlates well with the increase in area of the corrugated cell, impedance spectroscopy analyses were carried out in a similar way as for the fuel cell mode (Fig. 4d). ASR values for the serial and polarization resistances associated to the electrolyte and the electrodes, respectively, were listed in Table 1 after fitting the impedance spectra obtained at $V_{\mathrm{b}}$ $=1.3 \mathrm{~V}$ with an equivalent circuit (inset Fig. $4 \mathrm{~d}$ ). As observed in the fuel cell mode, the reduction in the ASR is equally distributed between the electrolyte and the electrode and can be proportionally ascribed to the increase of area, i.e. $\mathrm{ASR}_{\mathrm{corr}} / \mathrm{ASR}_{\text {plan }}=0.63$. This result confirms that the corrugation is equivalent to a direct increase of the area, even in co-electrolysis mode.

Finally, in order to corroborate the quality of the printed cells and the capability of reaching quality standards similar to the current state of the art cells fabricated by conventional techniques, a mid-term degradation test was carried out on the

Table 1 Values of area specific resistance (total, electrolyte and electrode contributions) obtained from equivalent circuit fitting of the EIS spectra for both planar and corrugated cells measured in fuel cell and co-electrolysis mode at $900{ }^{\circ} \mathrm{C}$

\begin{tabular}{|c|c|c|c|c|c|c|}
\hline & \multicolumn{3}{|l|}{ SOFC mode } & \multicolumn{3}{|c|}{ Co-electrolysis mode } \\
\hline & $\operatorname{ASR}_{\text {plan }}\left(\Omega \mathrm{cm}^{2}\right)$ & $\operatorname{ASR}_{\text {corr }}\left(\Omega \mathrm{cm}^{2}\right)$ & $\mathrm{ASR}_{\text {corr }} / \mathrm{ASR}_{\text {plan }}$ & $\operatorname{ASR}_{\text {plan }}\left(\Omega \mathrm{cm}^{2}\right)$ & $\operatorname{ASR}_{\text {corr }}\left(\Omega \mathrm{cm}^{2}\right)$ & $\mathrm{ASR}_{\text {corr }} / \mathrm{ASR}_{\text {plan }}$ \\
\hline Total & 1.10 & 0.65 & 0.6 & 1.20 & 0.70 & 0.6 \\
\hline Electrolyte & 0.50 & 0.30 & 0.6 & 0.55 & 0.30 & 0.6 \\
\hline Electrodes & 0.60 & 0.35 & 0.6 & 0.65 & 0.40 & 0.6 \\
\hline
\end{tabular}




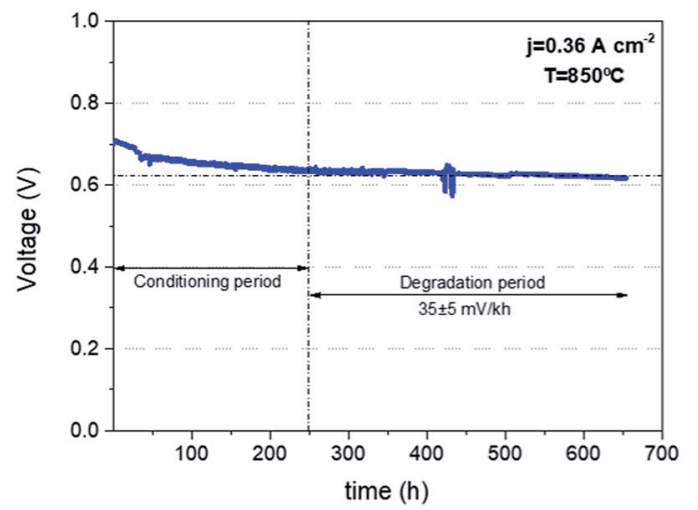

Fig. 5 Mid-term stability test carried out during $650 \mathrm{~h}$ for a corrugated cell measured at $850{ }^{\circ} \mathrm{C}$ and a fixed current density of $j=360 \mathrm{~mA}$ $\mathrm{cm}^{-2}$. A standard period of $250 \mathrm{~h}$ of conditioning is considered before the degradation test of $400 \mathrm{~h}$.

corrugated cell operating in fuel cell mode. Fig. 5 shows the voltage evolution as a function of time for a galvanostatic experiment fixing a current density of $j=360 \mathrm{~mA} \mathrm{~cm}{ }^{-2}$ at $850{ }^{\circ} \mathrm{C}$. After an initial conditioning period of $250 \mathrm{~h}$ (typically required to stabilize the behaviour of a $\mathrm{SOFC}^{45}$ ), the degradation of the cell was measured over $400 \mathrm{~h}$ showing a remarkably stable behaviour. A low degradation rate of $35 \pm 5 \mathrm{mV} / 1000 \mathrm{~h}$ was measured indicating a good behaviour according to the combination of materials used in the fabrication of the cell. Overall, it is confirmed that the $3 \mathrm{D}$ printing structuration of the electrolyte carried out in this work represents a straightforward method to enhance the performance of solid oxide cells for both fuel cell and electrolysis applications, obtaining an enhancement directly proportional to the increase in area as a first approximation. Moreover, the performance stability proved in SOFC mode anticipates the future impact of this technology approach for real applications, especially, when considering their lower environmental impact compared to conventional manufacturing techniques as recently reported by the authors. ${ }^{\mathbf{4 6}}$

\section{Conclusions}

Electrolyte-supported solid oxide cells with both conventional (planar) and enhanced-area (corrugated) architectures were successfully fabricated with ceramic 3D printing technologies. Fully functional dense and crack-free yttria-stabilized zirconia electrolytes were $3 \mathrm{D}$ printed reaching an ionic conductivity as high as $3.0 \times 10^{-2} \mathrm{~S} \mathrm{~cm}^{-1}$ at $800{ }^{\circ} \mathrm{C}$ in the planar and corrugated geometries. 3D printed solid oxide cells with planar geometry presented a good performance (comparable to conventional cells) in both fuel cell and co-electrolysis mode. More interestingly, corrugated cells showed an improvement straightforwardly proportional to the increase of their active area achieved by 3D structuration. In this work, a direct increase of $60 \%$ on conventional SOFC technology (LSM-YSZ/YSZ/NiYSZ) was reached obtaining an excellent maximum power density of $410 \mathrm{~mW} \mathrm{~cm} \mathrm{~cm}^{-2}$ at $900{ }^{\circ} \mathrm{C}$. Similarly, a high current density of $600 \mathrm{~mA} \mathrm{~cm}^{-2}$ at $1.3 \mathrm{~V}$ was injected in a corrugated solid oxide electrolysis cell operating in co-electrolysis mode. Moreover, a remarkably low degradation of the enhanced cells were proved in durability tests of $600 \mathrm{~h}$ of duration even at highcurrent density conditions $\left(j=360 \mathrm{~mW} \mathrm{~cm}^{-2}\right.$ at $\left.850{ }^{\circ} \mathrm{C}\right)$. These exceptional results can be considered the first step for the fabrication of a radically new generation of solid oxide cells with enhanced performance related to their change in nature from planar to three-dimensional. This enhancement goes beyond the high-aspect ratio of their corrugated electrolyte and includes 3D printed structural elements with embedded functionality and improved stackability. The 3D printing methodology of this work represents a versatile approach that increases the design freedom for highly performing and durable complex devices and a step forward in the revolution of the additive manufacturing in the energy sector.

\section{Conflicts of interest}

There are no conflicts to declare.

\section{Acknowledgements}

The authors want to acknowledge the financial support of the "Generalitat de Catalunya" (2017 SGR 1421, NANOEN) and the Spanish Ministry of Science and Innovation (ENE2016-74889C4-1-R, 3D-MADE). This work has also received funding from the Fuel Cells and Hydrogen 2 Joint Undertaking (JU) under grant agreement No 874577 .

\section{Notes and references}

1 R. Peters, R. Deja, M. Engelbracht, M. Frank, V. N. Nguyen, L. Blum and D. Stolten, J. Power Sources, 2016, 328, 105-113. 2 R. Payne, M. Kah and J. Love, ECS Trans., 2009, 25, 231-239. 3 I. Frenzel, A. Loukou, D. Trimis, F. Schroeter, L. Mir, R. Marin, B. Egilegor, J. Manzanedo, G. Raju, M. De Bruijne, R. Wesseling, S. Fernandes, J. M. Chaves Pereira, G. Vourliotakis, M. Founti and O. Posdziech, Energy Procedia, 2012, 28, 170-181.

4 Final Report Summary - RELHY Grant agreement ID: 213009. Innovative Solid Oxide Electrolyser Stacks for Efficient and Reliable Hydrogen Production, 2011.

5 S. D. Ebbesen and M. Mogensen, J. Power Sources, 2009, 193, 349-358.

6 F. Tietz, Mater. Sci. Forum, 2003, 426-432, 4465-4470.

7 M. A. Borik, S. I. Bredikhin, V. T. Bublik, A. V. Kulebyakin, I. E. Kuritsyna, E. E. Lomonova, P. O. Milovich, V. A. Myzina, V. V. Osiko, P. A. Ryabochkina and N. Y. Tabachkova, J. Am. Ceram. Soc., 2017, 100, 5536-5547. 8 C. Zhang, C. J. Li, G. Zhang, X. J. Ning, C. X. Li, H. Liao and C. Coddet, Mater. Sci. Eng., B, 2007, 137, 24-30.

9 K. Wincewicz, C. Keegan and C. S. Joyce, J. Power Sources, 2005, 140, 280-296.

10 E. D. Wachsman and K. T. Lee, Science, 2011, 334, 935-939. 11 M. A. Laguna-Bercero and V. M. Orera, Int. J. Hydrogen Energy, 2011, 36, 13051-13058. 
12 M. Morales, V. Miguel-Pérez, A. Tarancón, A. Slodczyk, M. Torrell, B. Ballesteros, J. P. Ouweltjes, J. M. Bassat, D. Montinaro and A. Morata, J. Power Sources, 2017, 344, 141-151.

13 M. Morales, A. Pesce, A. Slodczyk, M. Torrell, P. Piccardo, D. Montinaro, A. Tarancón and A. Morata, ACS Appl. Energy Mater., 2018, 1, 1955-1964.

14 P. C. Su, C. C. Chao, J. H. Shim, R. Fasching and F. B. Prinz, Nano Lett., 2008, 8, 2289-2292.

15 C. Cheng-Chieh, C.-M. Hsu, Y. Cui and F. B. Prinz, ACS Nano, 2011, 5, 5692-5696.

16 J. B. Lafon, C. Chaput, R. Gaignon and C. Delange, Additional Conferences (Device Packaging, HiTEC, HiTEN, \& CICMT), 2011, pp. 000261-000265.

17 M. Schwentenwein and J. Homa, Int. J. Appl. Ceram. Technol., 2015, 12, 1-7.

18 J. C. Ruiz-Morales, A. Tarancón, J. Canales-Vázquez, J. Méndez-Ramos, L. Hernández-Afonso, P. Acosta-Mora, J. R. Marín Rueda and R. Fernández-González, Energy Environ. Sci., 2017, 846-859.

19 M. A. Sukeshini, F. Meisenkothen, P. Gardner and T. L. Reitz, J. Power Sources, 2013, 224, 295-303.

20 M. A. Sukeshini, R. Cummins, T. L. Reitz and R. M. Miller, J. Am. Ceram. Soc., 2009, 92, 2913-2919.

21 R. I. Tomov, M. Krauz, J. Jewulski, S. C. Hopkins, J. R. Kluczowski, D. M. Glowacka and B. A. Glowacki, J. Power Sources, 2010, 195, 7160-7167.

22 L. Wei, J. Zhang, F. Yu, W. Zhang, X. Meng, N. Yang and S. Liu, Int. J. Hydrogen Energy, 2019, 44, 6182-6191.

23 B. Xing, C. Cao, W. Zhao, M. Shen, C. Wang and Z. Zhao, J. Eur. Ceram. Soc., 2019, 40, 1418-1423.

24 A. M. Sukeshini, R. Cummins, T. L. Reitz and R. M. Miller, Electrochem. Solid-State Lett., 2009, 12, B176.

25 C. Li, H. Shi, R. Ran, C. Su and Z. Shao, Int. J. Hydrogen Energy, 2013, 38, 9310-9319.

26 C. Li, H. Chen, H. Shi, M. O. Tade and Z. Shao, J. Power Sources, 2015, 273, 465-471.

27 G. D. Han, K. C. Neoh, K. Bae, H. J. Choi, S. W. Park, J. W. Son and J. H. Shim, J. Power Sources, 2016, 306, 503-509.

28 N. Yashiro, T. Usui and K. Kikuta, J. Eur. Ceram. Soc., 2010, 30, 2093-2098.
29 H. Shimada, F. Ohba, X. Li, A. Hagiwara and M. Ihara, J. Electrochem. Soc., 2012, 159, F360-F367.

30 V. Esposito, C. Gadea, J. Hjelm, D. Marani, Q. Hu, K. Agersted, S. Ramousse and S. H. Jensen, J. Power Sources, 2015, 273, 89-95.

31 C. Gadea, Q. Hanniet, A. Lesch, D. Marani, S. H. Jensen and V. Esposito, J. Mater. Chem. C, 2017, 5, 6021-6029.

32 S. Masciandaro, M. Torrell, P. Leone and A. Tarancón, J. Eur. Ceram. Soc., 2019, 39, 9-16.

33 T. Chartier, C. Hinczewski and S. Corbel, J. Eur. Ceram. Soc., 1999, 19, 67-74.

34 C. Chaput and T. Chartier, RTejournal - Forum für Rapid Technol., 2007, 4, 1-15.

35 C. Hinczewski, S. Corbel and T. Chartier, J. Eur. Ceram. Soc., 1998, 18, 583-590.

36 C. Bae, A. Ramachandran, K. Chung and S. Park, Annu. Rev. Mater. Res., 2017, 54, 470-477.

37 C. Ahamer, A. K. Opitz, G. M. Rupp and J. Fleig, J. Electrochem. Soc., 2017, 164, F790-F803.

38 J. A. Cebollero, R. Lahoz and A. Larrea, J. Power Sources, 2017, 360, 336-344.

39 J. A. Cebollero, R. Lahoz, M. A. Laguna-Bercero, J. I. Peña, A. Larrea and V. M. Orera, Int. J. Hydrogen Energy, 2017, 42, 13939-13948.

40 L. Blum, W. A. Meulenberg, H. Nabielek and R. SteinbergerWilckens, Int. J. Appl. Ceram. Technol., 2005, 2, 482-492.

41 S. C. Singhal and K. Kendall, High-temperature Solid Oxide Fuel Cells: Fundamentals, Design and Applications, 2003.

42 A. Bertei, F. Tariq, V. Yufit, E. Ruiz-Trejo and N. P. Brandon, J. Electrochem. Soc., 2017, 164, F89-F98.

43 M. Geagea, J. Ouyang, B. Chi, F. Delloro, A. Chesnaud, A. Ringuedé, M. Cassir and A. Thore, ECS Trans., 2015, 68, 2961-2969.

44 J. Onishi, Y. Kametani, Y. Hasegawa and N. J. Shikazono, J. Electrochem. Soc., 2019, 166, F876-F888.

45 A. Hornés, M. Torrell, A. Morata, M. Kendall, K. Kendall and A. Tarancón, Int. J. Hydrogen Energy, 2017, 42, 13889-13901. 46 V. Ferreyra, D. Wolff, A. Hornés, A. Morata, M. Torrell, A. Tarancón and C. Corchero, Life Cycle Assessment of a 5 $\mathrm{kW}$ SOFC stack manufacturing via 3D printing technology, Appl. Energy, submitted. 